H. Queiroga, M.R. Cunha, A. Cunha, M.H. Moreira, V. Quintino, A.M. Rodrigues, J. Serôdio \& R.M. Warwick (eds),

Marine Biodiversity: Patterns and Processes, Assessment, Threats, Management and Conservation

DOI 10.1007/s10750-005-1112-6

\title{
Probing diversity in the plankton: using patterns in Tintinnids (planktonic marine ciliates) to identify mechanisms
}

\author{
John R. Dolan*, Rodolphe Lemée, Stéphane Gasparini, Laure Mousseau \& Céline Heyndrickx \\ Marine Microbial Ecology Group, Laboratoire d'Océanographie de Villefranche, CNRS UMR 7093, Station Zoologique, \\ B. P. 28F-06230, Villefranche-Sur-Mer, France \\ (*Author for correspondence: E-mail: dolan@obs-vlfr.fr)
}

Key words: biogeography, biodiversity, zooplankton, Mediterranean, latitudinal gradient, phytoplankton, foraminifera

\begin{abstract}
In diversity research, the use of survey data appears to have declined in favour of experimental or modeling approaches because direct relationships are difficult to demonstrate. Here we show that use of field data can yield information concerning the mechanisms governing diversity. First, we establish that tintinnids display a global latitudinal pattern of diversity similar to other pelagic organisms; species numbers appear to peak between $20^{\circ}$ and $30^{\circ}$ north or south. This common large scale spatial trend has been attributed to the gradient in water column structure across the global ocean. We then examine the generality of a relationship between planktonic diversity and water column structure by considering data from the Mediterranean Sea, in which water column structure changes seasonally. Among populations of foraminifera, tintinnids, and the dinoflagellates of the genus Ceratium, we compare data from trans-Mediterranean sampling conducted at different times and monthly changes in species richness at single sites. We find that water column structure alone appears to be a poor predictor of temporal changes in diversity. Lastly, we present an example of temporal changes in tintinnid diversity based on data from an oceanographic sampling station in the N. W. Mediterranean where resources, as chlorophyll, appear distinctly unrelated to changes in water column structure. We show that short-tem temporal changes in diversity (week to week shifts) can be related to changes in chlorophyll concentration. We conclude that in tintinnids diversity can be directly linked to characteristics of food resources.
\end{abstract}

\section{Introduction}

Three major approaches are commonly employed in diversity research: experimentation, modeling, and survey, each of which possesses particular weaknesses. Here, after briefly reviewing the drawbacks of recent experimental and modeling efforts, we will illustrate the major problem involved in using survey data - that of distinguishing direct effects on diversity from co-varying or indirect factors. To show the utility of survey data we will begin by establishing the validity of using tintinnid ciliates as an example of a typical planktonic group. Then, we will use survey data to explore factors co-varying with tintinnid diversity to determine if a plausible controlling mechanism influencing diversity can be identified.

The experimental approach has been employed most commonly to investigate the relationship between a single ecosystem function (production, nutrient regeneration, etc.) and diversity. Typically experimentation with planktonic communities has involved very simple petri dish or test tube communities of a few microbial species (e.g., Naeem \& Li, 1998; Naeem et al., 2000) or even strains of the same species (e.g. Buckling et al., 2000; Kassen et al., 2000). Thus, conclusions have been drawn from short-term results with very rudimentary 
communities. Extrapolation to the natural world has proven problematic especially as the little work which has been conducted by altering large, natural systems (such as whole lakes - e.g., Dodson et al., 2000), suggests that idiosyncratic, in other words unpredictable, results may be common. It is perhaps worth noting that with regard to marine benthic communities, experimentation with very simple communities has also shown 'idiosyncratic' effects of biodiversity on ecosystem function (Emmerson et al., 2001) or the existence of 'synergistic interactions' (Worm et al., 2002).

Modeling is an approach most often employed as a method to identify the factors governing diversity. The theoretical framework of modeling plankton communities can be traced back to Hutchinson's "Paradox of the Plankton" (1961) in which three major mechanisms were proposed: (1) symbiosis or commensalism, (2) predation, and (3) non-equilibrium conditions. In recent years, theoretical studies have suggested the primacy of each of these mechanisms. Thus, species oscillations can explain diversity as non-equilibrium conditions are likely the rule (Huisman \& Weissing, 1999) or specialization among predators or consumers is important (Hulot et al., 2000) as well as facilitation or commensalism (Loreau \& Hector, 2001).

The survey approach-determining, and then attempting to explain, natural patterns of species abundance is the most time-honored as it dates back at least to Darwin (1859). The obvious drawback is that mechanisms governing biodiversity can only be inferred by co-variation and covariation need not indicate causation. An excellent example of this has been reported with regard to planktonic foraminifera.

From the point of view of past and present species distributions, foraminifera are no doubt the best-studied marine planktonic group (Caron \& Swanberg, 1990). Paleotemperatures can be estimated from oxygen isotopes in fossil tests (e.g., Wilf et al., 2003) and at least in fossil assemblages, the co-variation of diversity and annual average sea surface temperature permit the estimation of past climatic change (e.g., Williams \& Johnson, 1975). Diversity appears fairly predictable from the type of environment (Ottens \& Nederbragt, 1992). Among living foraminifera communities in the Atlantic, species diversity was recently shown to be tightly correlated with annual sea-surface temperature, in a curvi-linear manner yielding maxima at 20-30 rather than a peak at the equator (Rutherford et al., 1999). The correlation was explained as due to the relation between annual sea surface temperature and both the depth and seasonality of the thermocline in the water column. Annual sea surface temperature appeared to be a proxy measure of the depth of the surface layer and therefore habitat volume for planktonic foraminifera somehow reflecting quantities of niches available for different species (Rutherford et al., 1999). However, the parameters which define or differentiate the niches are unknown.

Interestingly, molecular work has shown the existence of 'cryptic species' of foraminifera (de Vargas et al., 1999), that is morphologically very similar but genetically distinct populations. The genetically distinct populations appear to inhabit regions differing in productivity (de Vargas et al., 1999) or water column stability (de Vargas et al., 2002). Careful examination of the different 'strains' has also revealed apparently subtle morphological differences in, for example, shell porosity. However, once again what ecologically differentiates the populations is unknown.

In copepods, among the mechanisms thought to maintain diversity, specialization in feeding may be much less important than the effects of predators (McGowan \& Walker, 1980). In an environment characterized by a structured water column, i.e., with a well-defined thermocline, predation pressure may be stronger yielding greater diversity than environments with mixed water columns (McGowan \& Walker, 1980, 1985; Longhurst, 1985). However, with regard to planktonic foraminifera, we are in a poor position to begin to identify what mechanism (food, predation, etc.) may be important in influencing diversity. We know relatively little about foraminiferan nutrition and growth (Caron et al., 1995) or trophic specialization (Swanberg \& Caron, 1991) or their predators (Caron \& Swanberg, 1990). In contrast to foraminifera, a fair amount is known about tintinnid ciliates.

Tintininnids are ciliates of the microzooplankton; they are characterized by the possession of a species-specific shell or lorica, shaped like a bowl or vase or tube, within which the ciliate cell can 
withdraw (Fig. 1). While generally a small part of the ciliate community, they are much more abundant than foraminifera or radiolarians (Thompson et al., 1999) and there is a wealth of data on their ecology (see Dolan, 2000; Dolan et al., 2002).

As most planktonic ciliates, tintinnids are found largely in the surface layer of the sea where they feed on algae ranging in size from 2 to 20 microns. The generation times of tintinnids are similar to other planktonic ciliates and their algal prey (potentially a few hours). The dimensions of their lorica, specifically the diameter of the oral (or mouth) end, are related to their food. The oral diameter of the lorica is about four times the diameter of the prey ingested most efficiently (Dolan et al., 2002). Tintinnids are fed upon by a large variety of taxa. The stomach contents of larval fish contain tintinnids almost as frequently as copepods (Turner, 1984). Different metazoan zooplankters are also known to feed on tintinnids ranging from copepods to gelatinous zooplankton (Stoecker \& Capuzzo, 1990). However, given their numerical dominance among the zooplankton, copepods are generally thought to be the major predators of tintinnids. Interestingly, there appears to be no clear relationship between the size of a tintinnid's lorica and its suceptability to predation by copepods (Stoecker \& Capuzzo, 1990; Dolan \& Gallegos, 2001), although most experimental work has been conducted with coastal species of copepods.

Like foraminifera and radiolarians, species identifications can be made using characteristics of gross morphology, with some caveats (for recent discussions see Cariou et al., 1999; Dolan, 2000; Dolan \&
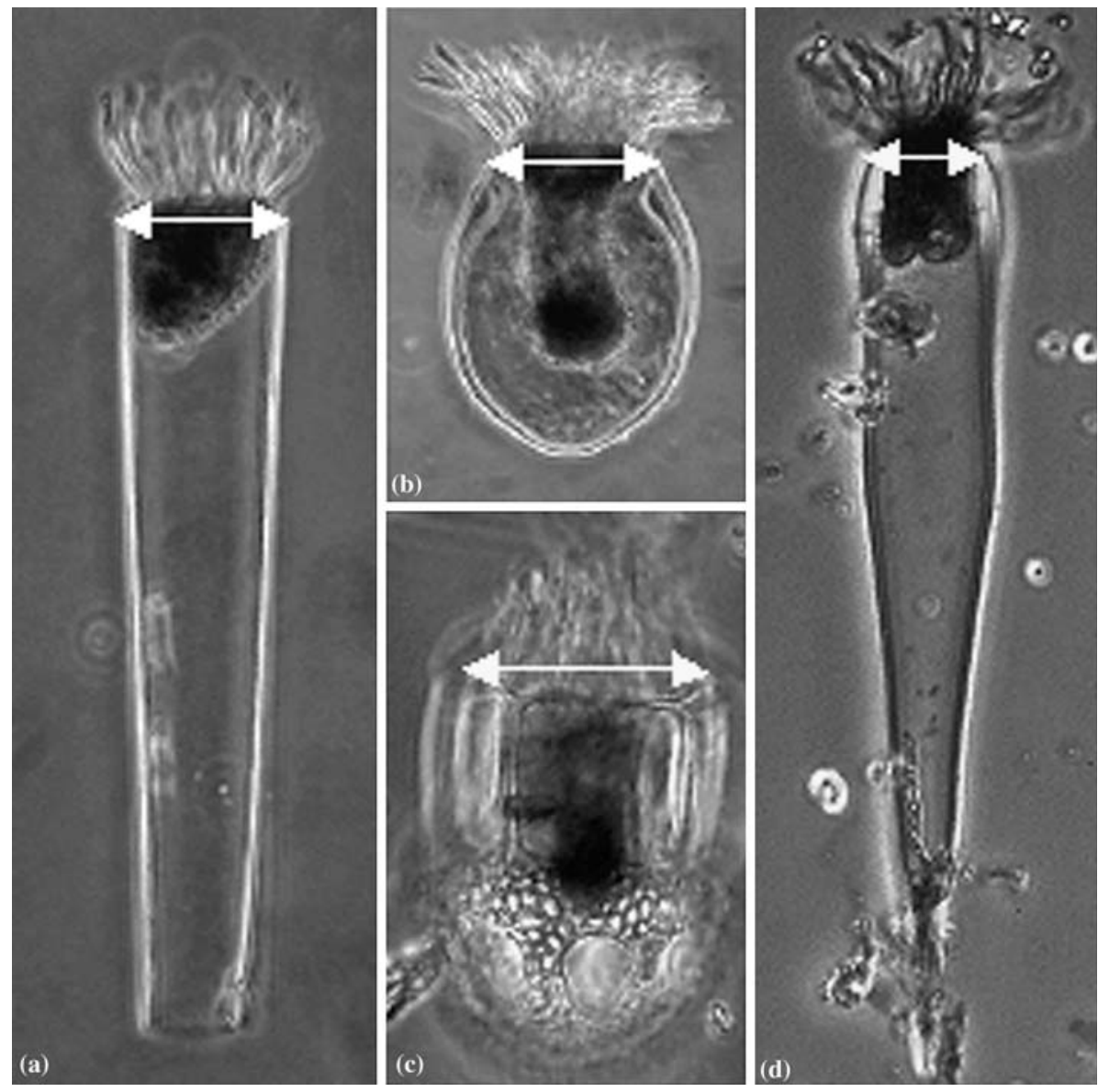

Figure 1. Photomicrographs of Tintinnids. Lugol's -preserved specimens collected from the Bay of Villefranche, N. W. Mediterranean Sea. Arrows indicate the oral opening, lorica oral diameter (LOD) of the lorica or shell into which the ciliate cell may withdraw. (a) Eutintinnus fraknoii, LOD $=40 \mu \mathrm{m}$. (b) Proplectella fastigata, LOD $=40 \mu \mathrm{m}$. (c). Dictyocysta lepida, LOD $=45 \mu \mathrm{m}$., (d) Xystonellopsis brandti LOD $=25 \mu \mathrm{m}$. 
Gallegos, 2001; Modigh \& Castaldo, 2002). Tintinnids have the further advantage of representing a monophyletic group, even among competing ciliate classification schemes (e.g., Petz \& Foissner, 1992; Lynn \& Small, 1997). Recent molecular work (Snoeyenbos-West et al., 2002; Agatha et al., 2005) has largely confirmed the classical (based on morphology) taxonomic classification of tintinnids. Tintinnids are united ecologically as microzooplankters, morphologically as loricate ciliates, and phylogenetically as members of the order Tintinnida.

Before examining patterns of diversity in tintinnids, the first question one might ask is whether tintinnids are a typical or atypical group of plankters. That is, do tintinnids show a global pattern of diversity similar to other planktonic groups such as foraminifera and copepods and phytoplankton taxa or a 'microbial' pattern of "all species are everywhere" sensu Fenchel \& Findlay (1997). Thus, this will be the first issue considered. Secondly, the relationship between water column structure and diversity among planktonic organisms will be considered. Temporal trends of diversity relative to water column structure in a system characterized by seasonal changes in water column stratification - the Mediterranean Sea, will be explored with regard to foraminifera, tintinnids and dinoflagellates of the genus Ceratium. Thirdly, changes in diversity will be examined at an oceanographic sampling station in the N. W. Mediterranean where resources, as chlorophyll, appear distinctly unrelated to changes in water column structure.

\section{Methods}

\section{Global distribution of tintinnid species abundance}

Literature reports furnishing species abundance for single points in time and space were used. When species abundance were given for more than one date, the date with maximum number of species was taken. Use of a single date from reports giving more than one measure was used to make such reports comparable to those of oceanographic campaigns, which formed the majority of the data points, giving a single estimate per location. No attempt was made to sort data by the sampling technique employed (i.e., plankton net tows or whole water collection). The oceano- graphic campaign reports and research reports (Table 1) yielded a large number of data points $(n=451)$ with a near complete latitudinal coverage of $81^{\circ} \mathrm{N}$ to $75^{\circ} \mathrm{S}$. The data base assembled represents a greatly expanded version of that previously presented (Dolan \& Gallegos, 2001) which consisted of 168 data points.

\section{Water column stratification and Mediterranean plankton}

The link between water column structure and diversity was considered by examining reports of foraminifera community composition across the Mediterranean in the autumn when the Mediterranean is stratified and during winter mixis. Seasonal trends were considered by examining reports of species abundance at a single location over an annual cycle for tintinnids and dinoflagellates of the genus Ceratium. The relationship of tintinnid diversity with the size of the mixed layer, as indicated by the depth of the chlorophyll maximum layer, at the beginning and end of the stratified period was examined.

Data on foraminifera (species richness and lnbased $\mathrm{H}^{\prime}$ values) were based on a report of foraminifera community composition derived from sampling at 13 stations across the Mediterranean in autumn 1986 and 14 stations in winter 1988 (Pujol \& Vergnaud Grazzini, 1995: Table 2). Data on species richness by month for tintinnids and a group of phytoplankters-dinoflagellates of the genus Ceratium was obtained from Rampi (1948: p. 53) based on material collected from 1938 to 1939 in the N. W. Mediterranean Sea near San Remo, Italy. The relationship between the depth of the chlorophyll maximum layer and tintinnid species richness or diversity (as $\mathrm{H}^{\prime}$ ) at the beginning of the stratified period was examined using data from Dolan (2000: Fig. 1) based on samples obtained in June 1993 (Dolan \& Marrasé, 1995) and May-June 1996 (Dolan et al., 1999). The relationship at the end of the stratified period was explored using data from Dolan et al., (2002: Figs. 2 and 3) based on sampling conducted in September 1999.

\section{Temporal trends of tintinnid diversity}

We examined tintinnid populations in the Bay of Villefranche in samples from a standard station 
Table 1. Sources of data used to construct plots of latitude vs. species abundances

\begin{tabular}{|c|c|c|c|}
\hline Study site & Latitude range & $N$ & Reference \\
\hline Barents Sea & $72-70^{\circ} \mathrm{N}$ & 6 & Jensen \& Hansen (2000) \\
\hline Barents Sea & $73-81^{\circ} \mathrm{N}$ & 12 & Boltovskoy et al. (1991) \\
\hline Chesterfield Inlet Estuary & $64-63^{\circ} \mathrm{N}$ & 12 & Rogers et al. (1981) \\
\hline Skagerak (N Sea) & $58^{\circ} \mathrm{N}$ & 1 & Hedin (1974) \\
\hline Bedford Basin, NS & $44^{\circ} \mathrm{N}$ & 1 & Paranjape (1987) \\
\hline Bay of Fundy & $45-42 \mathrm{~N}$ & 3 & Middelebrook et al. (1987) \\
\hline Damariscotta estuary & $44^{\circ} \mathrm{N}$ & 1 & Sanders (1987) \\
\hline Akkeshi Bay, JP & $43^{\circ} \mathrm{N}$ & 1 & Taguchi (1976) \\
\hline Coastal Mediterranean & $43^{\circ} \mathrm{N}$ & 1 & Cariou et al. (1999) \\
\hline Narragansett Bay & $42^{\circ} \mathrm{N}$ & 1 & Hargraves (1981) \\
\hline Long Island Sound & $41^{\circ} \mathrm{N}$ & 1 & Gold \& Morales (1975) \\
\hline Long Island Sound & $41^{\circ} \mathrm{N}$ & 1 & Capriuolo \& Carpenter (1983) \\
\hline Open Mediterreanean & $41-34^{\circ} \mathrm{N}$ & 23 & Dolan $(2000)$ \\
\hline Atlantic-Mediterreanean & $43-31^{\circ} \mathrm{N}$ & 11 & Dolan (2002) \\
\hline Lagoa de Obidos, PT & $40^{\circ} \mathrm{N}$ & 1 & Silva (1953) \\
\hline Chesapeake Bay & $39-37^{\circ} \mathrm{N}$ & 9 & Dolan \& Gallegos (2001) \\
\hline Atlantic & $29-60^{\circ} \mathrm{N}$ & 62 & Garder (1946) \\
\hline South Pacific Coastal & $12^{\circ} \mathrm{N}$ & 1 & Gold \& Morales (1977) \\
\hline Sub \& Tropical Pacific & $34^{\circ} \mathrm{N}-25^{\circ} \mathrm{S}$ & 62 & Kofoid \& Campbell (1939) \\
\hline Atlantic \& Pacific & $64^{\circ} \mathrm{N}-39^{\circ} \mathrm{S}$ & 160 & Campbell (1942) \\
\hline New Zealand Coastal & $42-50^{\circ} \mathrm{S}$ & 4 & James \& Hall (1995) \\
\hline Bahia Blanca Estuary & $38^{\circ} \mathrm{S}$ & 2 & Barria de Cao (1992) \\
\hline SW Atlantic Open & $34-60^{\circ} \mathrm{S}$ & 18 & Thompson et al. (1999) \\
\hline SW Atantic Shelf & $40-56^{\circ} \mathrm{S}$ & 16 & Thompson et al. (2001) \\
\hline S Atlantic & $59-60^{\circ} \mathrm{S}$ & 23 & Wasik \& Mikolajczk (1990) \\
\hline Ross Sea & $75^{\circ} \mathrm{S}$ & 1 & Monti \& Fonda Umani (1995) \\
\hline
\end{tabular}

$N$ value indicates the number of data points obtained. Note that out of a total of 451 points, the majority are from reports of oceanographic expeditions in which open water sites dominated (i.e., Kofoid \& Campbell, 1939; Campbell, 1942; Garder, 1946).

'Point B' $\left(43^{\circ} 41^{\prime} 10^{\prime \prime} \mathrm{N}, 7^{\circ} 19^{\prime} 00^{\prime \prime} \mathrm{E}\right)$. Sampling was conducted, in principle, weekly. Discrete depth samples from $0,10,20,30,40$, and $50 \mathrm{~m}$ were obtained using 51 Niskin bottles. Temperature and salinity were measured using a Seabird CTD. Chlorophyll $a$ samples were analyzed fluorometrically following acetone extraction. For tintinnids, a composite integrated water column sample of 41 was concentrated using a $20 \mu \mathrm{m}$ Nitex screen to $20 \mathrm{ml}$. This method yields tintinnid numbers as high as settling whole water samples (Pierce \& Turner, 1994). The entire concentrate, in 3-10 ml aliquots, was settled in sedimentation chambers and examined with an inverted microscope at $200 \times$. Based on previous studies, examining material from 41 of water likely yielded species abundances of about $50 \%$ of those found through examining large volumes (80 1) of water (Cariou et al., 1999). Tintinnids were identified using lorica morphology and the species descriptions found in Campbell (1942), Jörgensen (1924) and Kofoid and Campbell $(1929,1939)$. Here data from the 45 samples taken in 2002 (seven samples missing from equipment failure or bad weather) are presented.

\section{Results}

Global distribution of tintinnid species abundance

Plotting species richness, averaged over increments of $5^{\circ}$ latitude or individual points estimates (Fig. 2), gave the commonly found relationship between latitude and species abundance. In both 


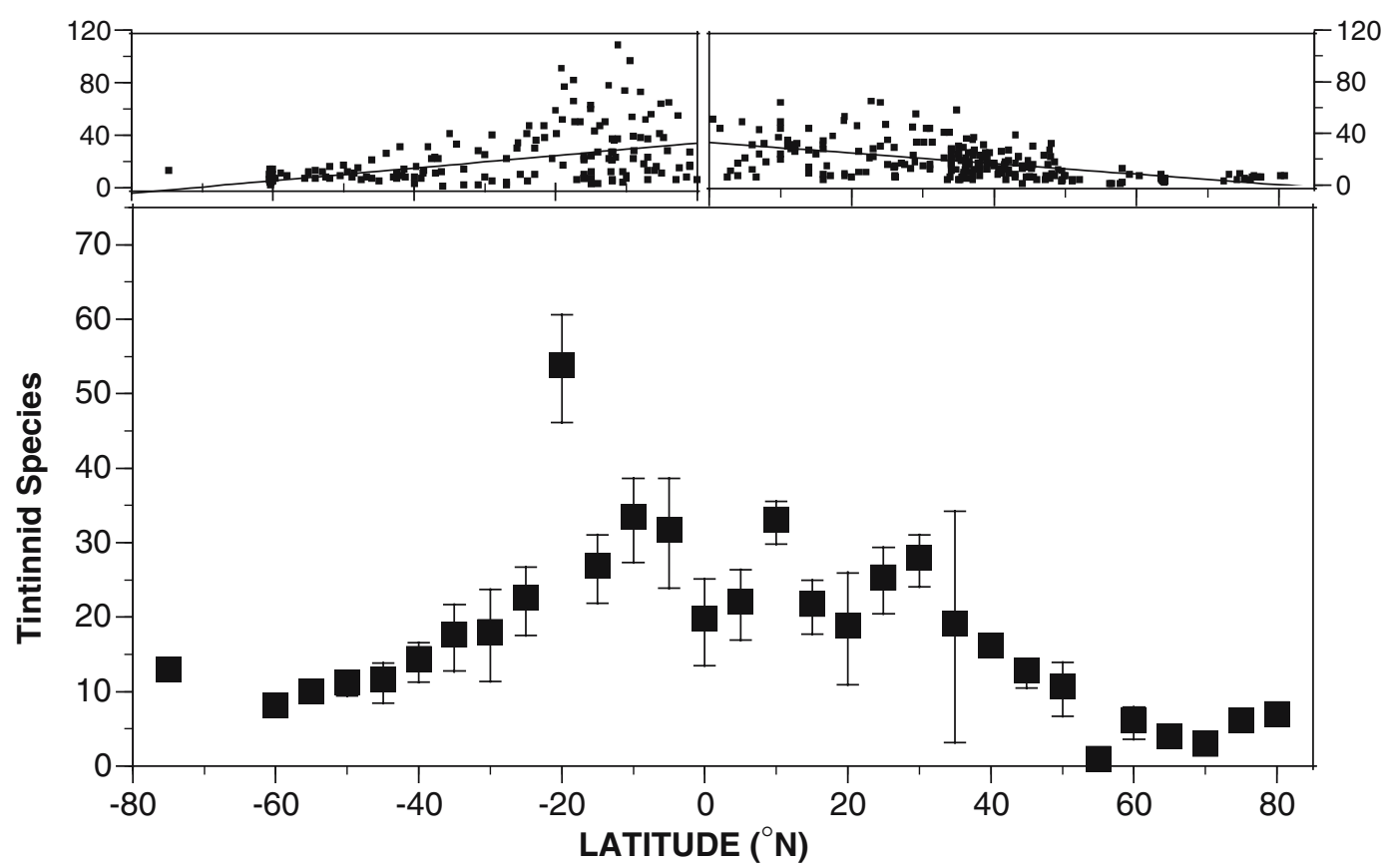

Figure 2. Latitudinal distribution of tintinnid species abundance based on reports given in Table 1. Top panels show individual data points. Bottom panel shows species abundances averaged within bands of $5^{\circ}$ of latitude, error bars indicate SE of the averages. Linear regression equation for the southern latitude estimates (individual data points) is $r=0.45, x=0.48 \times$ latitude +0.37 . Linear regression equation for the nothern latitude estimates (individual data points) is $r=0.53, x=0.41 \times$ latitude +0.33 .

the southern and northern hemispheres, species richness increases from the poles to lower latitudes with a peak around $20-30^{\circ}$ followed by a slight decline toward the equator. Quite similar equations describe the relationships between latitude and species richness for the northern and southern hemispheres (Fig. 2).

\section{Water column stratification and Mediterranean plankton}

Water column dynamics are well characterized for the Mediterranean Sea (e.g., Bethoux, 1989). The seasonal stratification of the water column begins in the spring and ends with mixis in autumn; the cool Mediterranean deep water is formed at the surface in winter. Superimposed on the seasonal changes in water column structure throughout the Mediterranean is a general west to east gradient of declining nutrient and chlorophyll concentrations as well as primary production. During the stratified period, there is also a marked gradient of increasing mixed layer depth from west to the east (e.g.,
Dolan et al., 1999). Thus, oligotrophy increases and when the surface mixed layer is present, from late spring to early autumn, the surface layer is larger and less productive going from the west to the east.

Comparing mixed and stratified conditions, for the foraminifera species richness appears higher in the stratified period comparing estimates across the Mediterranean for February and September (Fig. 3). However, the differences are neither large nor consistent and diversity appears about the same in the autumn compared to the winter. Thus, on a seasonal time scale, changes in water column structure do not appear to be directly relatable to changes in the diversity of planktonic foraminifera.

Now consider temporal changes at a single site. Based on monthly sampling at a coastal station, species richness of two trophically distinct populations, tintinnids and Ceratium of the phytoplankton, show similarities (Fig. 4). For both groups, species richness was highest during the unstratified winter period and lowest during the summer corresponding with the stratified period. 

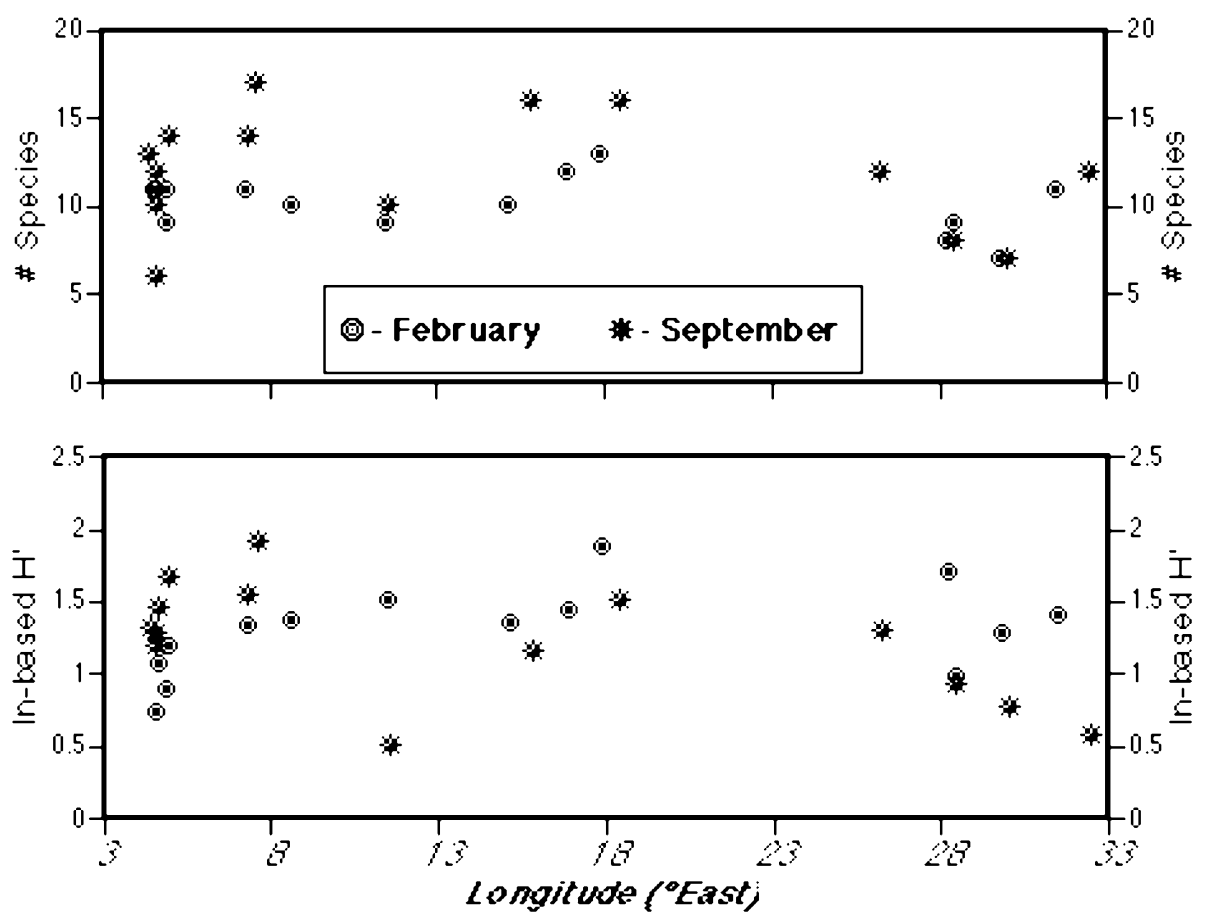

Figure 3. Estimates of the diversity of foraminifera across the Mediterrean Sea in February when the water column is mixed and September when the water colmumn is stratified based on data presented by Pujol \& Vergnaud Granzzini (1995). Note that species richness was generally higher in the September compared to February samples. However, this was not true of $\mathrm{H}^{\prime}$ values.

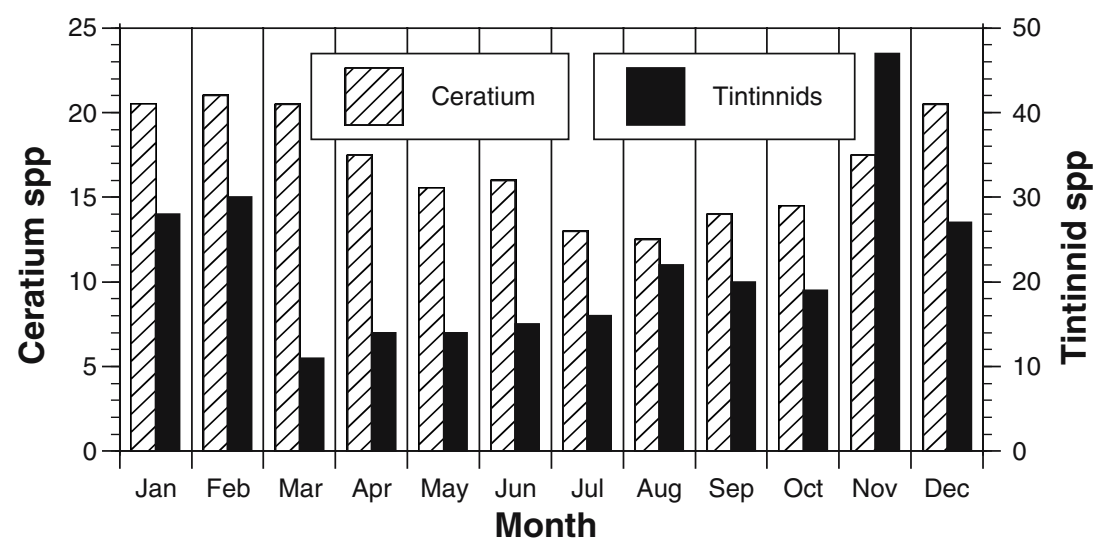

Figure 4. Species richness data by month for the phytoplankton genus Ceratium and tintinnids for waters off San Remo, N. W. Mediterrean Sea, based on a report by Rampi (1948). Note that species richness appears lowest during the summer and highest in the winter for the two trophically distinct groups of organisms.

Based on the admittedly weak evidence of monthly sampling, diversity as species richness (in two distinct groups) appears lowest in the structured, relatively stable water column of the summer.

A separate, and the last question with regard to the effect of structure of the water column, is that of comparing the characteristics of water columns structured to different degrees and at different times. A comparison of species richness and diversity $\left(\mathrm{H}^{\prime}\right)$ as a function of the depth of the chlorophyll maximum layer at the beginning and end of the stratified period shows very different 


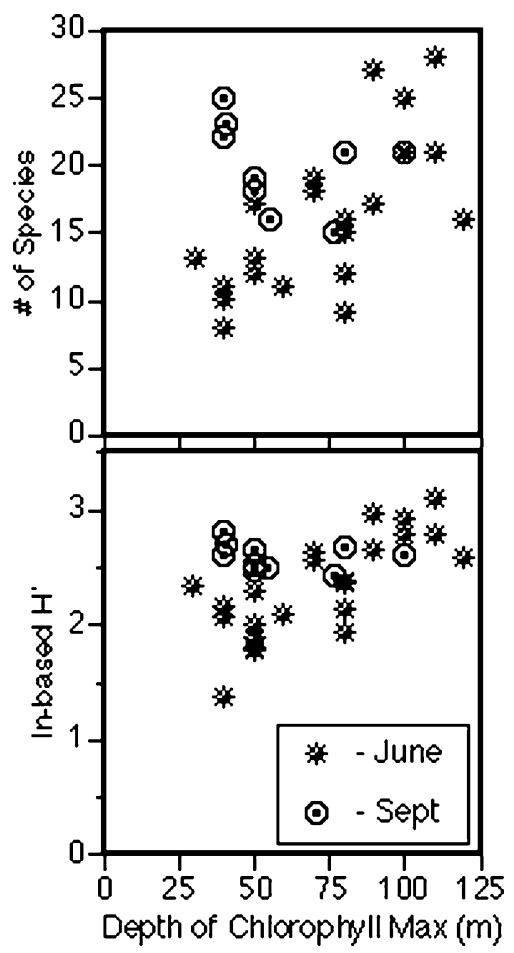

Figure 5. The relationship between species richness (top panel) or diversity as $\mathrm{H}^{\prime}$ (bottom panel) and the depth of the chlorophyll maximum layer in June, early in the season of the stratified water column, and in September, near the end of water colulmn stratification in the Mediterrean Sea. Data are from a variety of sites across the Mediterrean Sea taken from Dolan (2000) and Dolan et al., (2002).

trends (Fig. 5). Samples obtained in June from a transect across the Mediterranean show a positive relationship between the depth of the chlorophyll maximum layer and tintinnid diversity. In contrast, samples from a September transect do not show any particular relationship of species richness or $\mathrm{H}^{\prime}$ with the depth of the chlorophyll maximum layer. However, tintinnid diversity (both taxonomic and morphological) was relatable to the size structure of the phytoplankton community. Diversity of resources, roughly considered as size-classes of chlorophyll, was correlated with both morphological and species diversity of tintinnids (Dolan et al., 2002).

\section{Temporal trends of tintinnid diversity}

Water column stratification at "Point B" at the entrance to the Bay of Villefranche (N.W. Medi- terranean Sea) changes predictably with the season. An iso-thermic, well-mixed water column is typical of the winter months. Thermal stratification begins in mid-spring and a strongly stratified water column with a surface layer of about $10 \mathrm{~m}$ depth is typically present from June through September. Water column stratification breaks down in October and water temperatures are near isothermic by early winter. Interestingly, chlorophyll concentrations remain relatively low year-round $(0.2 \mu \mathrm{g}$ 1-1) with unpredictable peaks occasionally appearing (e.g., Dolan et al., 1995; Mostajir et al., 1995; Bustillo-Guzman et al., 1995). Thus, at Point B water column structure varies independently of algal stock, in other terms, food resources for zooplankton.

Data gathered in 2002 (Fig. 6) clearly shows the independence of water column structure, in the form of the difference in density between 0 and $75 \mathrm{~m}$, from chlorophyll concentration. Casual inspection of the graphs showing temporal changes in chlorophyll, stratification, tintinnid diversity and concentration reveals that water column stratification is unrelated to tintinnid concentrations and diversity. Chlorophyll trends however parallel those of tintinnid concentration, and species abundance appears more closely related to tintinnid than chlorophyll concentration.

Simple regression analysis confirms a significant relationship $(r=0.53)$ between chlorophyll and tintinnid concentration (Fig. 7). Species abundance and total concentration of tintinnids co-vary positively but are not significantly $(r=0.23)$ related (Fig. 7). Given that (1) chlorophyll determines tintinnid concentration and (2) species abundance varies with tintinnid concentrations, changes in chlorophyll should, through changing tintinnid concentrations, influence diversity. This can be examined by plotting weekly changes in chlorophyll against weekly changes in tintinnid diversity and this indeed shows that the two parameters are tightly related $(r=0.74)$. Thus, as a mechanism explaining temporal changes in diversity, chlorophyll or resources appears a likely mechanism, especially compared to water column structure. While we can not exclude other mechanisms, such as predation, the close relationship with changes in chlorophyll suggests a direct link. 

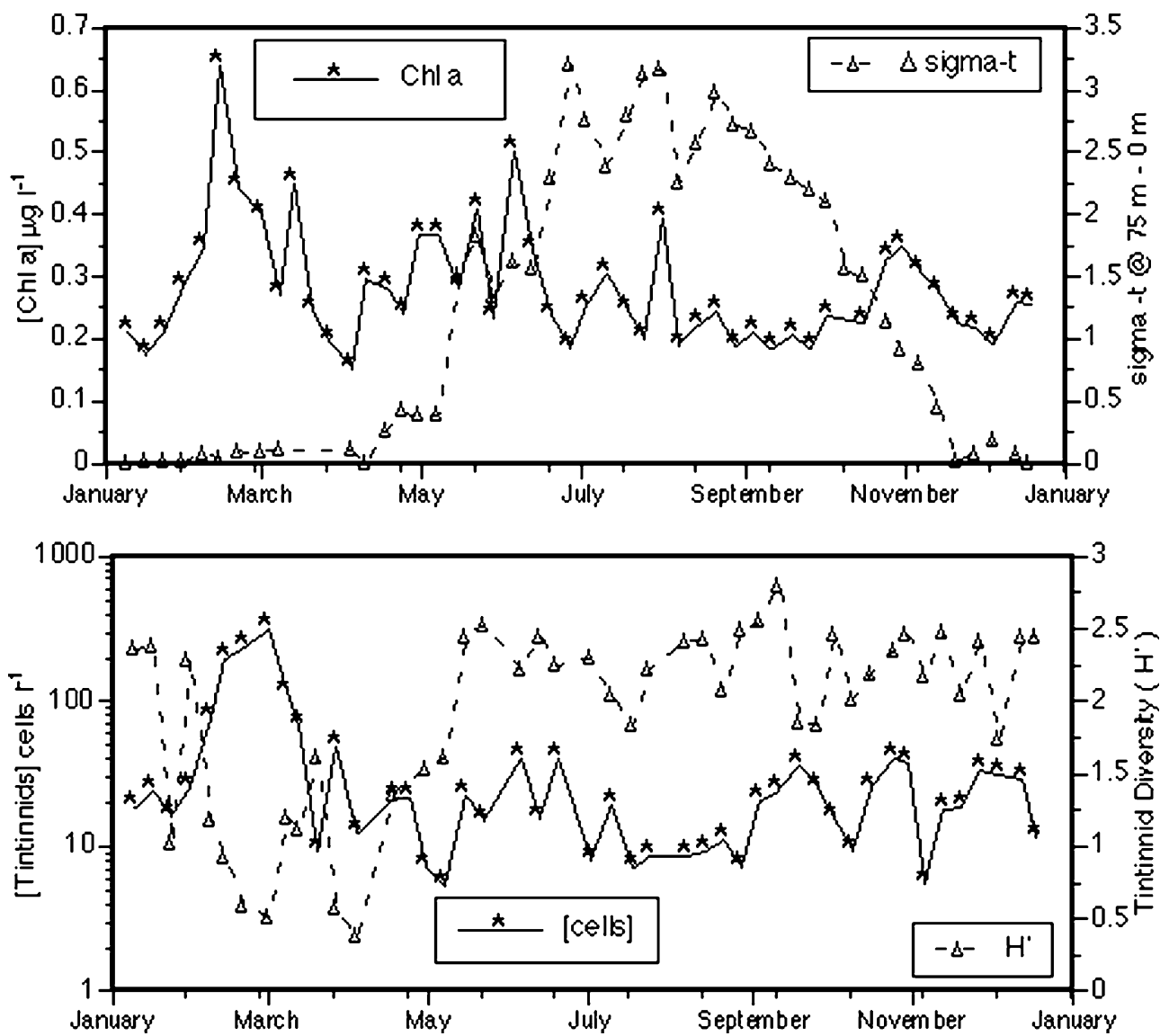

Figure 6. Temporal changes of water column characteristics and the tintinnid community at Point B, Bay of Villefranche in 2002, based on weekly sampling. Top panel shows changes in water column stratification and average chlorophyll concentration. Bottom panel shows species diversity and tintinnid concentrations.

\section{Discussion}

\section{Global distribution of tintinnid species abundance}

The pattern we found for tintinnid ciliates (species richness increases from the poles to lower latitudes with a peak around $20^{\circ}-30^{\circ}$ followed by a slight decline toward the equator) has been described for a very large variety of marine pelagic taxa ranging from tuna to foraminifera (Angel, 1993; Rutherford et al., 1999; Worm et al., 2003). Latitudinal diversity gradients are, of course, very well known among terrestrial taxa as well. Identification of factors underlying latitudinal diversity gradients has long been, and remains, a very active area of research (e.g., Gaston, 2000). The apparently common peaks of species richness at about $25^{\circ} \mathrm{N}$ or $25^{\circ} \mathrm{S}$, for example recently described for tintinnids through the Indian Ocean (Modigh et al., 2003), are intriguing. However, here we are not concerned with determining the underlying cause(s) of a latitudinal diversity gradient among tintinnid ciliates but rather simply demonstrating its existence.

The existence of a latitudinal gradient of species richness in tintinnids is of some significance because in other groups of ciliates, specifically benthic ciliates, global and local species richness are thought to be equal; that is all species are cosmopolitan and present in all locales, albeit in perhaps very difficult to detect concentrations (Fenchel et al., 1997; Finlay et al., 1998, 1999; Finlay, 2002). This conclusion has been drawn from the results of intensive examination and treatment (incubation of material to provoke excystment of 

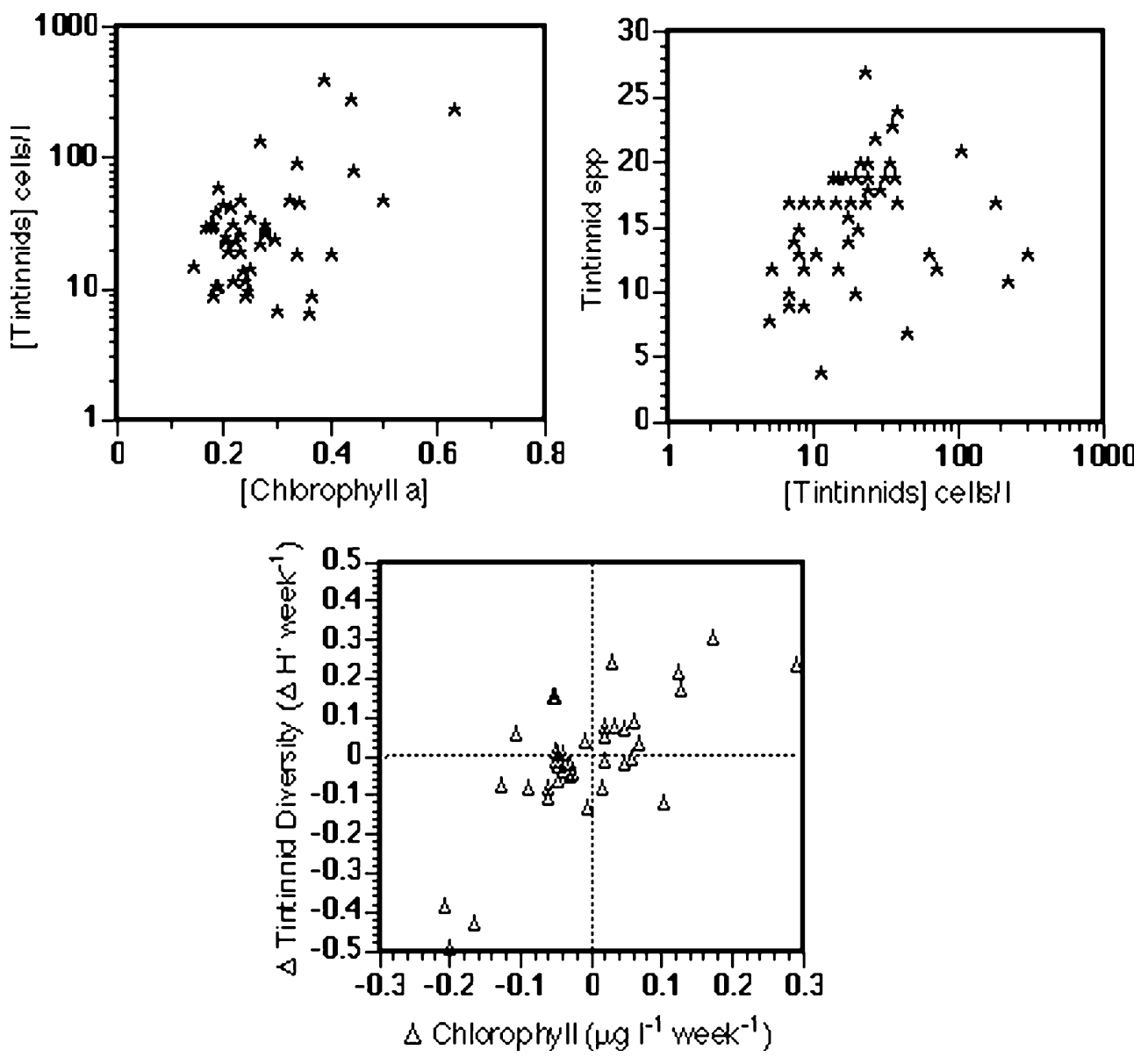

Figure 7. Scatter plots of the relationships between chlorophyll and tintinnid concentrations, tintinnid concentrations and species abundance, weekly changes in chlorophyll and tintinnid diversity as ln-based $\mathrm{H}^{\prime}$ Shannon values. Chlorophyll and tintinnid concentrations are significantly related $(r=0.53, n=45)$ : but tintinnid species richness is not related to tintinnid concentration. Weekly changes in chlorophyll are significantly related to weekly shifts in tintinnid diversity values $(r=0.74, n=40)$.

cysts, etc.) of samples yielding large and similar assemblages, regardless of sample origin. Thus, a latitudinal gradient in the species richness of benthic ciliates should not exist.

The mechanism behind ubiquitous distribution of species is ubiquitous dispersal which effectively prevents endemism (Finlay \& Esteban, 2004). Evidence at present can be found to support both global dispersal as well as endemism among marine microbes. For protists, there is evidence of wide dispersal as well as genetic isolation. For example, some taxa of foraminifera appear to experience genetic exchange between arctic and antarctic populations (Darling et al., 2000). In other species (defined morphologically), the quite similar morphologies mask genetic divergence be- tween arctic and antarctic populations (Darling et al., 2004). With regard to prokaryotes, the pattern of 'all species are everywhere' should presumably exist yet there is ample evidence of the existence of endemism among some taxa of freeliving prokaryotes (Hedlund \& Staley, 2004). One may conclude then, that while many microbes are everywhere not all are.

With regard to tintinnids, while many species are cosmopolitan, Figure 2 shows that global and local diversity do seem very different. Furthermore, tintinnids show a pattern of latitudinal diversity common among pelagic marine taxa. Confirmation of latitudinal changes in species richness of tintinnid communities was recently reported in a study of tintinnids between $29^{\circ}$ South 
and $60^{\circ}$ South in the southwestern Atlantic in which latitude was found to be associated with about $50 \%$ of the variability in diversity (Thompson, 2004). Nonetheless, it must be admitted that an apparent latitudinal gradient of species abundance does not disprove a cosmopolitan distribution of all species. A gradient in species abundance may simply reflect a gradient in the abundance of more or less distinct niches permitting the development and co-existence of more species.

What defines these niches is unknown. For example, it has been claimed that zooplankton diversity is not related to phytoplankton diversity but rather to phytoplankton biomass (Irigoien et al., 2004). However, these conclusions have been challenged (Dolan, 2005). Thus, even the relationship between zooplankton and phytoplankton diversity is unclear.

\section{Water column stratification and Mediterranean plankton}

In the Atlantic, the depth of the mixed layer has been proposed as a correlate of foraminferan species richness (Rutherford et al., 1999). Our examination of water column structure as an influence (direct or indirect) on diversity in Mediterranean plankton failed to provide evidence of a major rôle. Firstly, for Mediterranean populations of foraminifera, there appears to be little difference between species richness in February when the water column is mixed compared to September with a well-defined surface layer (Fig. 3). Secondly, historical reports based on monthly sampling for dinoflagellates (Ceratium) and tintinnids actually suggest the opposite. In coastal waters of the N. W. Mediterranean, species richness appears highest during late autumn and winter when the water column is subject to the most turbulent mixing (Fig. 4). Thirdly, data from transects across the Mediterranean Sea in June compared to September, showed distinct trends in tintinnid diversity despite similarities in water column structure (Fig. 5). Perhaps then, not unexpectedly, planktonic diversity does not show a simple relationship with water column structure.

\section{Temporal trends of tintinnid diversity}

The overall lack of a relationship between stratification of the water column and diversity was also seen in the temporal series from the Rade de Villefranche. At 'Point B' stratification follows regular seasonal trends while algal stock varies irregularly (Fig. 6). We found that diversity in tintinnids was loosely related to tintinnid abundance which was, in turn, loosely related to algal stock, measured as chlorophyll concentration. These relationships suggested that changes in chlorophyll (food resources) may be relatable to changes in diversity in tintinnids. Indeed, we found that the weekly changes in chlorophyll concentration were tightly correlated with shifts in tintinnid diversity (Fig. 7). Thus, as a mechanism controlling temporal changes in diversity, chlorophyll or resources appears a likely mechanism, especially compared to water column structure. While we can not exclude other mechanisms, such as predation, the close relationship with changes in chlorophyll suggests a direct link.

We should point out that the Rade de Villefranche may be an unusually dynamic system. For each season, the assemblage is generally dominated by $1-3$ species representing about $50 \%$ of the population and the identity of the seasonally dominate species has apparently varied comparing reports based on samples taken in the 1950s (Balech, 1959) and the 1970s (Rassoulzadegan, 1979). This is in contrast to the Bay of Naples in which species assemblages appear consistent since the 1930s despite considerable changes in nutrient input into the bay (Modigh \& Castalado, 2002). Thus, one might conclude that the Bay of Villefranche is an unusually dynamic system. However, the cycle of seasonal abundance in the bay (distinct peaks in late winter and late autumn separated by a summer minimum) appears common to the Western Mediterranean as it has been found in the Bay of Algers (Vitello, 1964) and the Gulf of Marseille (Travers, 1973). Large interannual (1952-1959) differences in the identity of the dominant tintinnid species have been found for waters off Blanes, Spain (Margalel, 1957, Margalef \& Morales, 1960). Thus, the relationships described for the Bay of Villefranche may be common. These relationships suggest that diversity appears more easily relatable to shifts in resources than the physical structure of the environment.

Diversity issues have taken center stage in many areas of biology. Fundamental points of view such as 'diversity is a characteristic of ecosystem func- 
tion' vs. 'diversity governs ecosystem function' are currently subjects of debate (Naeem, 2002). With regard to marine systems, a few years ago it was remarked that our understanding of marine pelagic biodiversity appears vague (Smetacek, 1996). This is probably due in part to the fact that different mechanisms proposed as important in maintaining diversity in pelagic populations are often closely related. Thus, a structured water column coincides with diverse and stable communities of phytoplankton, herbivorous copepods and predacious copepods (McGowan \& Walker, 1980, 1985; Venrick, 1990, 1999).

Here we have attempted to sort out possible mechanisms using field survey data established on different spatial and temporal scales. Tintinnid ciliates appear to be a reasonable model of marine pelagic organisms as their latitudinal diversity gradient pattern is similar to those found in a large variety of taxa. Considering a variety of data from the Mediterranean Sea, the seasonal appearance of a structured water column does not appear to be positively related to planktonic diversity. We showed that temporal changes in tintinnid diversity appeared unrelated to water column structure but could be linked to changes in resources. Thus, overall, resources appear to directly influence diversity.

\section{Acknowledgements}

We are grateful to the organizers of the 38th EMBS, H. Queiroga, M. Ribeiro da Cunha, M.-H. Moreira, V. Quintino, A.-M. Rodrigues, J. Serôdio, and M.-A. Cunha. A special thanks to H. Queiroga for an invitation to speak. Financial support for the work described here was provided by INSU of the CNRS through the project CNRSINSU ATI \#01N50/0388: "Effet du Mesozooplancton sur la Diversité des Compartiments Phyto et Microzooplanctonique d'une Zone Cotière Mediterraneene", the shared cost research project NTAP (contract no. EVK3-CT-2000-00022) of the EU RTD Programme "Environment and Sustainable Development" and forms part of the ELOISE projects cluster. This is ELOISE contribution no. 459/40 and a contribution of the PROOF program PROSOPE. Point B hydrological data were provided by the SOMLIT program
(CNRS-INSU) and are available through "www.obs-vlfr.fr/rade". Comments of the reviewers led to substantial improvements in this paper.

\section{References}

Agatha, S., M. C. Strûder-Kypke, A. Beran \& D. H. Lynn, 2005. Pelagostrobilidium neptuni (Montagnes and Taylor, 1994) and Strombidium biarmatum nov. spec. (Ciliophora, Oligotrichea): phylogenetic position inferred from morphology, ontogenesis, and gene sequence data. European Journal of Protistolology 41: 65-83.

Angel, M. V., 1993. Biodiversity of the Pelagic Ocean. Conservation Biology 7: 760-772.

Balech, E., 1959. Tintinnoinea del Mediterraneo. Trabajo Instituto Espanol de Oceanografia 28: 1-88.

Bethoux, J. P., 1989. Oxygen consumption, new production, vertical advection and environmental evolution in the Mediterranean Sea. Deep-Sea Research 36: 769-781.

de Barrio Cao, M. S., 1992. Abundance and species composition of Tintinnina (Ciliophora) in Bahia Blanca Estuary, Argentina. Estuarine Coastal Shelf Science 34: 295-303.

Bolotovskoy, D., S. M. Vivequin \& N. R. Swanberg, 1991. Vertical distribution of tintinnids and associated microplankton in the upper layer of the Barents Sea. Sarsia 76: 141-151.

Buckling, A., R. Kassen, G. Bell \& P. B. Rainey, 2000. Disturbance and diversity in experimental microcosms. Nature 408: 961-964.

Bustillo-Guzman, J., H. Claustre \& J. -C. Marty, 1995. Specific phytoplankton signatures and their relationship with hydrographic conditions in the coastal northwestern Mediterranean Sea. Marine Ecology Progress Series 124: 247-258.

Campbell, A. S., 1942. The Oceanic Tintinnoina of the Plankton Gathered During the Last Cruise of the Carnegie. Carnegie Institution of Washington, Publication 537, Washington D.C.

Capriulo, G. M. \& E. J. Carpenter, 1983. Abundance, species composition and feeding impact of tintinnid micro-zooplankton in central Long Island Sound. Marine Ecology Progress Series 10: 277-288.

Cariou, J.-B., J. R. Dolan \& S. Dallot, 1999. A preliminary study of tintinnid diversity in the NW Mediterranean Sea. Journal of Plankton Research 21: 1065-1075.

Caron, D. A. \& N. R. Swanberg, 1990. The ecology of planktonic sarcodines. Reviews in Aquatic Sciences 3: 147-180.

Caron, D. A., A. F. Michaels, N. R. Swanberg \& F. A. Howes, 1995. Primary productivity by symbiont-bearing planktonic sarcodines (Acantharia, Radiolaria, Foraminifera) in surface waters near Bermuda. Journal of Plankton Research 17: 103-129.

Darling, K. F., C. M. Wade, I. A. Stewart, D. Kroon, R. Dingle \& A. I. Brown, 2000. Molecular evidence for genetic mixing of artic and antarctic subpolar populations of planktonic foraminifers. Nature 405: 23-24.

Darling K. F., M. Kucera, C. J. Pudsey \& C. M. Wade, 2004. Molecular evidence links cryptic diversification in ploar planktonic protists to Quaternary climate dynamics. Pro- 
ceeding of the National Academy of Sciences USA 101: 7657-7662.

Darwin, C., 1859. On the Origin of Species by Means of Natural Selection. Facsimile edition. 1964. Harvard University Press, Boston, USA

Dodson, S. I., S. E. Arnott \& K. L. Cottingham, 2000. The relationship in lake communities between primary productivity and species richness. Ecology 81: 2662-2679.

De Vargas, C., R. Norris, L. Zaninetti, S. W. Gibb, \& J. Pawlowski, 1999. Molecular evidence of cryptic speciation in planktonic foraminifera and their relation to ocean provinces. Proceedings of the National Academy of Sciences USA 96: 2864-2868.

De Vargas, C., M. Bonzon, N. W. Tess, J. Pawlowski \& L. Zaninetti, 2002. A molecular approach to biodiversity and biogeography in the planktonic foraminifera Globigerinella siphonifera (d'Orbigny). Marine Micropaleontology 45: 101-116.

Dolan, J. R., 2000. Tintinnid ciliate diversity in the Mediterranean Sea: longitudinal patterns related to water column structure in late spring-early summer. Aquatic Microbial Ecology 22: 20-30.

Dolan, J. R., 2005. Marine ecology - different measures of biodiversity. Nature 433: E9 (Jan 27 2005).

Dolan, J. R \& C. L. Gallegos, 2001. Estuarine diversity of tintinnids (planktonic ciliates). Journal of Plankton Research 23: 1009-1027.

Dolan, J. R. \& C. Marassé, 1995. Planktonic ciliate distribution relative to a deep chlorophyll maximum: Catalan Sea, N. W. Mediterrean, June 1993. Deep-Sea Research 42: 1965-1987.

Dolan, J. R., T. F. Thingstad, \& F. Rassoulzadegan, 1995. Phosphate transfer between microbial size-fractions in Villefranche Bay (N. W. Mediterranean Sea) France in autumn 1992.

Dolan, J. R., F. Vidussi \& H. Claustre, 1999. Planktonic ciliates in the Mediterranean Sea: longitudinal trends. Deep-Sea Research I 46: 2025-2039.

Dolan, J. R., H. Claustre, F. Carlotti, S. Plounevez \& T. Moutin, 2002. Microzooplankton diversity: relationships of tintinnid ciliates with resources, competitors and predators from the Atlantic coast of Morocco to the eastern Mediterranean. Deep-Sea Research 1(49): 1217-1232.

Emmerson, M. C., M. Solan, C. Emes, D. M. Paterson \& D. Raffaell, 2001. Consistent patterns and the idiosyncratic effcts of biodiversity in marine ecosystems. Nature 411: 73-77.

Fenchel, T., G. F. Esteban \& B. Finlay, 1997. Local vs. global diversity of microorganisms: cryptic diversity of ciliated protozoa. Oikos 80: 220-225.

Finlay, B. J., 2002. Global dispersal of free-living microbial eukaryote species. Science 296: 1061-1063.

Finlay, B. J. \& G. F. Esteban, 2004. Ubiquitous dispersal of free-living microorganisms. In Bull, A. T. (ed.) Microbial Diversity and Bioprocessing. ASM Press, Washington D.C., USA: $216-224$.

Finlay, B. J., G. F. Esteban \& T. Fenchel, 1998. Protozoan diversity: converging estimates of the global number of freeliving ciliate species. Protist 149: 29-37.

Finlay, B. J., G. F. Esteban, J. L. Olmo \& P. A. Tyler, 1999. Global distribution of free-living microbial species. Ecography 22: $138-144$.
Garder, K. R., 1946. Tintinnoinea from the "Michael Sars" North Atlantic Deep-Sea Expedition, 1910. In Murray, J. \& J. Hjort, Report on the Scientific Results of the "Michael Sars" North Atlantic Deep-Sea Expedition, 1910. Bergen Musuem, Bergen, Norway.

Gaston, K. J., 2000. Global patterns in biodiversity. Nature 405: 220-227.

Gold, K. \& E. A. Morales, 1975. Seasonal changes in lorica sizes and the species of Tinntinida in the New York Bight. Journal of Protozoology 22: 520-528.

Gold, K. \& E. A. Morales, 1977. Studies on the Tintinnida of Enewetak Atoll. Journal of Protozoology 24: 580-587.

Hargraves, P. E., 1981. Seasonal variations of tintinnids (Ciliophora: Oligotrichida) in Narragansett Bay, Rhode Island. Journal of Plankton Research 3: 81-91.

Hedlin, B. P. \& J. T. Staley, 2004. Microbial endemism and biogeography. In Bull, A. T. (ed.) Microbial Diversity and Bioprocessing. ASM Press, Washington D.C, pp. 225-231.

Hedin, H., 1974. Tintinnids on the swedish west coast. Zoon 2: 123-133.

Huisman, J. \& J. F. Weissing, 1999. Biodiversity of plankton by species oscillations and chaos. Nature 402: 407-410.

Hulot, F. D., G. Lacroix, F. Lescher-Moutoué \& M. Loreau, 2000. Functional diversity governs ecosystem response to nutrient enrichment. Nature 405: 340-344.

Hutchinson, G. E., 1961. The paradox of the plankton. American Naturalist 95: 137-145.

Irigoien, X., J. Huisman \& R. P. Harris 2004. Global biodiversity patterns of marine phytoplankton and zooplankton. Nature 429: 863-867.

James, M. R. \& J. A. Hall, 1995. Planktonic ciliated protozoa: their distribution and relationship to environmental variables in a marine coastal ecosystem. Journal of Plankton Research 17: 659-683.

Jensen, F. \& B. W. Hansen, 2000. Ciliates and heterotrophic dinoflagellates in the marginal ice zone of the central Barents Sea during spring. Journal of the Marine Biological Association United Kingdom 18: 45-54.

Jörgensen, E., 1924. Mediterranean Tintinnidae. Report of the Danish Oceanographical Expeditions 1908-1910 to the Mediterranean and adjacent seas. Vol. II. Biology, No. 8, J.3 (Thor expedition), Copenhagen.

Kassen, R., A. Buckling, G. Bell \& P. B. Rainey, 2000. Diversity peaks at intermediate productivity in a laboratory microcosm. Nature 406: 508-512.

Kofoid, C. A. \& A. S. Campbell, 1929. A conspectus of the marine and fresh-water ciliate belonging to the suborder tintinnoinea, with descriptions of new species principally from the Agassiz expedition to the eastern tropical Pacific 1904-1905. University of California Publications in Zoology 34: 1-403.

Kofoid, C. A. \& A. S. Campbell, 1939. The tintinnoinea of the eastern tropical Pacific. Bulletin of the Museum of Comparative Zoology of Harvard College 84: 1-473.

Longhurst, A. R., 1985. Relationship between diversity and the vertical structure of the upper ocean. Deep-Sea Research 1(32): 1535-1570.

Loreau, M. \& A. Hector, 2001. Partitioning selection and complementarity in biodiversity experiments. Nature 412: 72-76. 
Lynn, D. H. \& E. B. Small, 1997. A revised classification of the phylum Ciliophora Doflein, 1901. Revista de la Sociadad de la Historia Naturale de Mexico 47: 65-78.

Margalel, R., 1957. Fitoplancton de las costas de Blanes (Gerona) de agosto de 1952 a junio de 1956. Investigaciones Pesqueras 8: 89-95.

Margalef, R. \& E. Morales, 1960. Fitoplancton de las costas de Blanes (Gerona) de julio de 1956 a junio de 1959. Investigaciones Pesqueras 16: 3-31.

McGowan, J. A. \& P. W. Walker, 1980. Structure in the copepod community of the North Pacific Central grye. Ecological Monographs 49: 195-226.

McGowan, J. A. \& P. W. Walker, 1985. Dominance and diversity maintenance in an oceanic ecosystem. Ecological Monographs 55: 103-118.

Middlebrook, K., C. W. Emerson, J. C. Roff \& D. H. Lynn, 1987. Distribution and abundance of tintinnids in the Quoddy region of the Bay of Fundy. Canadian Journal of Zoology 65: 594-601

Modigh, M. \& S. Castaldo, 2002. Variability and persistence in tintinnid assemblages in a Mediterranean coastal site. Aquatic Microbial Ecology 28: 299-311.

Modigh, M., S. Castalado, M. Saggiomi \& I. Santarpia, 2003. Distribution of tintinnid species from $42^{\circ} \mathrm{N}$ to $43^{\circ} \mathrm{S}$ through the Indian Ocean. Hydrobiologia 503: 251-262.

Monti, M. \& S. Fonda Umani, 1995. Tintinnids in Terra Nova Bay - Ross Sea during two austral summers (1987/88 and 1989/90). Acta Protozoologica 34: 193-201.

Mostajir, B., J. R. Dolan \& F. Rassoulzadegan, 1995. Seasonal variations of pico- and nano-detrital particles (DAPI Yellow Particles DYP) in the Ligurian Sea (NW Mediterranean). Aquatic Microbial Ecology 9: 267-277.

Naeem, S., 2002. Ecosystem consequences of biodiversity loss: the evolution of a paradigm. Ecology 83: 1537-1552.

Naeem, S. \& S. Li, 1998. Consumer species richness and autrophic biomass. Ecology 79: 2603-2615.

Naeem, S., D. R. Hahn \& G. Schuurman, 2000. Producerdecomposer co-dependency influences biodiversity effects. Nature 403: 762-764

Ottens, J. J. \& A. J. Nederbragt, 1992. Planktic foraminferal diversity as an indicator of ocean environment. Marine Micropaleontology 19: 13-28.

Paranjape, M., 1987. Grazing by microzooplankton in the Eastern Canadian Arctic in summer 1983. Marine Ecology Progress Series 40: 239-246.

Petz, W. \& W. Foissner, 1992. Morphology and morphogenesis of Strobilidium caudatum (Fromentel), Meseres corlissi N. Sp., Halteria graninella (Müller), and Strombidium rehwaldi N. Sp., and a proposed phylogenetic system for oligotrich ciliates (Protozoa, Ciliophora). Journal of Protozoology 39: 159-176.

Pierce, R. W. \& J. T. Turner, 1994. Plankton studies in Buzzards Bay, Massachusetts, USA. IV. Tintinnids, 1987 to 1988. Marine Ecology Progress Series 112: 235-240.

Pujol C. \& C. Vergnaud Grazzini, 1995. Distribution patterns of live planktic foraminifers as related to regional hydrography and productive systems of the Mediterranean Sea. Marine Micropaleontology 25: 187-217.

Rassoulzadegan, F., 1979. Evolution annuelle des ciliés pélagiques en Méditerranée nord-occidentale. II. Cilés oligo- triches. Tintinnides (Tintinnia). Investigaciones Pesqueras 43: 417-488.

Rampi, L., 1948. Tinttinnoidi delle acque di San Remo. Bollettino di Pesca, di Pisciocoltura e di Idrobiologia 24: $5-11$.

Rogers, G. F., J. C. Roff \& D. H. Lynn, 1981. Tintinnids of Chesterfield Inlet, Northwest Territories. Canadian Journal of Zoology 59: 2360-2364.

Rutherford, S., S. D'Hondt \& W. Prell, 1999. Environmental controls on the geographic distribution of zooplankton diversity. Nature 400: 749-752.

Sanders, R. W., 1987. Tintinnids and other microzooplanktonseasonal distributions and relationships to resources and hydrography in a Maine estuary. Journal of Plankton Research 9: 65-77.

Smetacek, V., 1996. Biodiversity and production in the water mass. In Hempel, G. (ed.) The Ocean and the Poles. Gustav Verlag, , Jena: 207-216.

Snoeyenbos-West, O. L. O., T. Salcedo, G. B. McManus \& L. A. Katz, 2002. Insights into the diversity of choreotrich, oligotrich ciliates (Class: Spirotrichea) based on genealogical analyses of multiple loci. International Journal of Systematic and Evolutionary Microbiology 52: 1901-1913.

Silva, E. S., 1953. Estudos de plancton na Lagoa de Obidos II. Tintinnoinea. Revista de Faculdadae de Ciencias de Lisboa 2a Serie C 11: 97-116.

Stoecker, D. K. \& J. M. Capuzzo, 1990. Predation on protozoa: its importance to zooplankton. Journal of Plankton Research 12: 891-908.

Swanberg, N. R. \& D. A. Caron, 1991. Patterns of sarcodine feeding in epipelagic oceanic plankton. Journal of Plankton Research 13: 287-312.

Taguchi, S., 1976. Microzooplankton and seston in Akkeshi Bay, Japan. Hydrobiologia 50: 195-204.

Thompson, G. A., 2004. Tintinnid diversity trends in the southwestern Atlantic Ocean $\left(29-60^{\circ} \mathrm{S}\right)$. Aquatic Microbial Ecology 35: 93-130.

Thompson, G. A., V. A. Alder, D. Boltovskoy \& F. Brandini, 1999. Abundance and biogeography of tintinnids (Ciliophora) and associated microzooplankton in the Southwestern Atlantic Ocean. Journal of Plankton Research 21: 1265-1298.

Thompson, G. A., V. A. Alder \& D. Boltovskoy, 2001. Tintinnids (ciliophora) and other net microzooplankton $(>30 \mu \mathrm{m})$ in southw-western Atlantic Shelf break waters. P.S.Z.N. Marine Ecology 22: 343-355.

Travers, M., 1973. Le microplancton du Golfe de Marseille: variations de la composition systématique et de la densité des populations. Tethys 5: 31-53.

Turner, J. T., 1984. The Feeding Ecology of Some Zooplankters that are Important Prey Items of Larval Fish. NOAA Technical Report NMFS 7. NOAA, Washington D.C $28 \mathrm{pp}$.

Venrick, E. L., 1990. Phytoplankton in an oligotrophic ocean: species structure and interannual variability. Ecology 71: $1547-1563$.

Venrick, E. L., 1999. Phytoplankton species structure in the central North Pacific, 1973-1996: variability and persistence. Journal of Plankton Research 21: 1029-1042. 
Vitiello, P., 1964. Contribution à l'étude des tintinnides de la baie d'Alger. Pelagos 2: 5-41.

Wasik, A. \& E. Mikolajczyk, 1990. Tintinnids near pack-ice between South Shetland and the South Orkney Islands (26 Dec. 1988 - 18 Jan. 1989). Acta Protozoologica 29: 229-244. Wilf, P., K. R. Johnson \& B. T. Huber, 2003. Correlated terrestrial and marine evidence for global climate changes before mass extinction at the Cretaceous-Paleogene boundary. Proceedings of the National Academy of Sciences, USA 100: 599-604.
Williams, D. F. \& W. C. Johnson II, 1975. Diversity of recent planktonic foraminifera in the southern Indian Ocean and late Pleistocene paleotemperatures. Quaternary Research 5: 237-250.

Worm, B., H. K. Lotze, H. Hillebrand \& U. Sommer, 2002. Consumer versus resource control of species diversity and ecosystem functioning. Nature 417: 848-851.

Worm, B., H. K. Lotze \& R. A. Myers, 2003. Predator diversity hotspots in the blue ocean. Proceedings of the National Academy of Sciences, USA 100: 9884-9888. 